\title{
Питання психології
}

УДК $87.717+241.631$

DOI: $10.33099 / 2617-6858-21-62-4-96-105$

Олійник А. В. кандидат психологічних наук, доцент кафедри теоретичної та практичної психології IППО, Національного університету «Львівська політехніка» https://orcid.org/0000-0002-2543-4281

\section{ПРЕВЕНЦІЯ СУЇЦИДАЛЬНОСТІ ЗАСОБАМИ РЕЛІГІЙНОЇ ВІРИ У СЕРЕДОВИЩІ СТУДЕНТСЬКОЇ МОЛОДІ}

У даній статті у ході поглибленого аналізу проблеми виливу віри в Бога на суїицальність суб 'єкта теоретично обгрунтовано та експериментально доведено значущий антисуйицальний вплив релігійної віри на свідомість та поведінку сучасного украӥнського студентства; емпірично встановлено гармонізуючий вплив віри в Бога на психіку студентської молоді: обтрунтовано особливості превенції суйицдальності та психокорекиї суїиидально небезпечних станів засобами релігійної віри й відтак, необхідності формування ставлення до життя як до найвищої людської иінності й ставлення до самогубства як до зазіхання на найбільш цінне.

Ключові слова: аутодеструктивність; релігійна віра; суӥиид; студентська молодь; превениія.

Актуальність теми. Зростання рівня суїцидальної активності у світі пояснює необхідність подальшого поглибленого дослідження проблеми, пошук ефективних шляхів протидії формуванню суїцидальних тенденцій, розширення системи превентивно-профілактичних заходів появи аутодеструктивності. 3 року в рік збільшується чисельність наукових праць, присвячених пошуку найбільш дієвих із них, але як засвідчують статистичні дані щодо рівня суїцидальності у світі, чисельність аутодеструктивних дій продовжує зростати, причому серед різних верств населення. Особливо турбує зростання суїцидальності у молодіжному середовищі.

Зрозуміло, що цілком позбавити суспільство суцїцидальних тенденцій неможливо, враховуючи усі індивідуальнопсихологічні особливості та чинники їх формування, але 3 метою мінімізації аутодеструктивних дій у світі слід шукати найбільш ефективні шляхи гармонізації душевного стану людини, формування стійких життєствердних антисуїцидальних диспозицій.

Значущим життєствердним потенціалом володіє релігійна віра, яка сприяє гармонізації психіки індивіда, позбавляючи мук переживання екзистенційного абсурду, вселяє сенс людського існування.

Мета статті полягають в обгрунтуванні ефективності життєствердного потенціалу релігійної віри у протидії суїцидальності у середовищі студентства, розширенні системи превентивно-профілактичних заходів появи аутодеструктивності.

Завдання статті: здійснити поглиблений теоретико-емпіричний аналіз проблеми впливу релігійної віри на суїцидальність суб'єкта та обгрунтувати особливості впливу релігійної віри в аспекті iii протидії суїцидальним тенденціям $\mathrm{y}$ середовищі студентства.

Теоретичне підгрунтя. Теоретикометодологічною основою дослідження стали концепція тлумачення релігійної віри як «вершини свідомості» В.Г.Джемса; концепції Е.З.Фромма, представників гуманістичного підходу у психології (А.Х.Маслоу, Г.У.Олплорта, К.Р.Роджерса) щодо значущого життєствердного потенціалу Віри в Бога; логотерапія В.Е.Франкла; психологія релігії В.П.Москальця (тлумачення релігійної віри як потужного чинники протидії суїцидальності).

Методи дослідження. $\mathrm{y}$ процесі теоретичного та емпіричного вивчення проблеми використовувались як 


\section{Питання психології}

загальнонаукові, так і спеціальні методи дослідження: теоретичні: аналіз наукової літератури, комплексний, гіпотетикодедуктивний та порівняльний методи, систематизація та узагальнення отриманої інформації, класифікація; емпіричні: спостереження, бесіда, діагностичні методи (Л. Собчик СМДО, методика диференціальної діагностики депресивних станів Зунге, опитувальник Б. Любан-Плоцца для визначення ризику суїциду, опитувальник Н. Пезешкіана для діагностики осіб iз суїцидальними тенденціями, авторська анкета для виявлення взаємозв'язку релігійної віри 3 суїцидальними тенденціями в середовищі студентської молоді); математичної статистики: параметричні та непараметричні критерії розрізнення; експериментальні матеріали, отримані під час дослідження, піддавалися статистичній обробці за допомогою спеціалізованого пакету прикладних програм для психологічних досліджень.

Результати і обговорення. Нехтування духовно-моральними

руйнування ідеалів, які висвітлюють особистості життєву перспективу, сприяє зростанню суїцидонебезпечних настроїв у суспільстві. У сучасному суспільстві зростає чисельність самотніх, розчарованих людей, молодь не знаходить смислу життя, заповнюючи екзистенційний вакуум алкоголем та наркотиками. Життєві негаразди, безробіття, самотність, крах надій, усвідомлення безперспективності майбутнього, алкоголізм, наркоманія, зростання злочинності, меркантилізм на тлі бездуховності - така ситуація сьогодення перебуває у прямому зв'язку із суїцидальністю. Люди живуть без чітких критеріїв цінності життя. У сучасному індустріалізованому світі, де 3 кожним роком поглиблюється процес формалізації, раціоналізації, меркантилізації, відчуження стало звичним у людських взаємостосунках, й майже не залишилося нічого, що могло б утримати від падіння на самісіньке дно кризи: «хвороба» цивілізацією, перекреслює в душах індивідів усе, що могло б зберегти їх віру у високий сенс життя.

Самогубство є своєрідним варіантом відповіді на екзистенційну кризу. Самогубство як явище індивідуальне існувало в усі часи, але іноді воно стає явищем соціальним, коли створюється сприятлива для нього суспільна атмосфера. Суїцидент - самоневдоволена людина, перебуває у конфлікті 3 діючими суспільними цінностями, які не приймає його власна природа. Суспільство завжди певним чином впливає на індивіда. Реалії світу (аморальність, цинізм, боротьба за виживання) суперечать істинній людській сутності, призводять до девальвації гуманістичних цінностей, розчарування, депресії, й відтак - до самогубства. Визначальним чинником такої ситуації у світі стало послаблення віри в Бога, орієнтації на високодуховні ідеали та цінності. Життя без ідеалів чи 3 бездуховними ідеалами й тяжкі розчарування є сприятливими щодо суїцидальності $[9,49]$.

Виникнення психологічних проблем індивіда, зокрема суїцидальних, перебуває у прямому зв'язку із зростанням суспільної бездуховності. У сучасному світі спостерігається жахлива асиметрія. Виявляється вона у тому, що основні зусилля особистості спрямовані на утилітарні цінності нестабільного зовнішнього світу, внаслідок чого iї життя стає обмеженим i дисгармонійним через загрозу втрати значущих зв'язків, статусу, власності. Життя, позбавлене надособистісного смислу, спрямоване виключно на задоволення меркантильно-споживацьких цілей, пов'язане 3 відчаєм, розчаруванням та песимізмом.

Досліджуючи проблему суїциду, психологічного здоров'я особи та суспільства, З.Фройд висловив припущення, що вимоги людської природи й суспільства можуть конфліктувати між собою в силу їх недосконалості; суспільство загалом може бути хворим. Обгрунтовуючи цю думку, ввів поняття «соціальний невроз» (нестача любові та уваги зі сторони інших, неможливість 


\section{Питання психології}

досягти гармонії із соціальною структурою суспільства), як соціальну зумовленість поширених нервово-психічних розладів [9, 93].

На духовне падіння суспільства як основну причину поширення аутодеструктивних тенденцій у психіці індивідів вказував Е.Фромм. Він намагався довести, наскільки морально хворе суспільство зі спотвореними ідеалами небезпечне для індивіда, стаючи джерелом думок про смерть та самогубство. У світі, в якому, «мати» панує над «бути», володіння над буттям, «мертве», механічне - над живим, цивілізація замінила Бога. Любов до усього штучного, усього того, що не росте, не розвивається, стало основою сьогодення, замість любові до істинного, природного того, що утверджує й піднімає цінність людського життя. Замість того, щоб цінити найпрекрасніший дар Бога, любити себе та інших, люди знецінюють життя, утверджуючи натомість хибні смисли існування [13, $461-483]$.

Про вплив суспільства на суїцидальні нахили молоді у роботі «Батьки і діти їх самогубці» говорить В.Федоров, звинувачуючи цивілізацію у тому, що вона спричинила його (суспільства) моральне падіння [11].

Сучасна урбанізована культура робить людину самотньою, вона не персоналізується, а лише аномізується, страждає, не витримує самотності як чи не єдиного середовища самоформування. Нестерпне почування самотності, надмірний індивідуалізм, байдужість, глибокі особистісні розчарування призводять до формування депресивно-невропатичних деструкцій у психіці індивідів, які $\epsilon$ психологічним базисом суїцидальності.

На всезагальну байдужість, відсутність моральних ідеалів, духовних орієнтирів буття як чинник зростання суїцидальності у суспільстві вказував i автор теорії еволюційного песимізму Е.Гартман: доводив, що еволюція світового процесу примножує суму болю: у світі сума болю більша, аніж сума задоволення $[10,49]$.
У концептуальному полі суспільнобездуховної детермінації суїцидальності знаходиться й фрустраційна концепція М.Ельнера, побудована на потужній емпіричній базі. Вчений уперше співставив 22 змінні соціально-економічного, географічного та нозологічного значення 3 показниками суїцидальності у великій кількості країн. За допомогою факторного аналізу було зроблено висновок, що високі показники суїцидальності пов'язані 3 негативними тенденціями сучасного технократичного суспільства $[10,20]$.

Цей каузальний зв'язок переконливо постав у дослідженні російського науковця А.Ф.Коні, проведеного на початку XX ст. Узагальнивши дані, нагромаджені вітчизняною та світовою статистикою суїцидів за століття, він пов'язав основну причину суїцидальності 3 відсутністю високих суспільних ідеалів [10, 19 - 20].

Основною причиною зростання чисельності самогубств М.О.Бердяєв також вважав підміну власне людських потреб технократичними. Він був переконаний, що техніка, яка виробляє предмети та знаряддя нищення життя, влада речей та грошей створюють химери та фантазії й спрямовують людину на хибні фікції, які лише створюють враження реальності. Духовність, яка на думку мислителя, завжди пов'язана із Богом, є здобуттям внутрішньої сили, опірності, протидії владі світу та суспільства над людиною. Людський дух, за М.Бердяєвим, завжди повинен прагнути до трансцендентності - того, що перевищує людину, й лише за такої умови вона не «втратить» саму себе, а навпаки, досягне щастя і гармонії [2, 165 - 167$]$.

Людська цивілізація, на думку М.О.Бердяєва, потребує глибокого духовного оновлення. Трагізм людського існування значною мірою залежить від закритості людей одне від одного, від слабкості тієї синтезувальної духовності, що веде до внутрішньої єдності особистості та єднання людини $з$ людиною. Це - духовне єднання людей, яке $є$ одним із шляхів у боротьбі проти гнітючих настроїв, що ведуть до 


\section{Питання психології}

самогубства, а не єдність еротична, що, навпаки, роз'єднує, вороже налаштовує одне проти одного $[1,8]$.

Видатний французький соціолог Е.Дюркгайм зростання чисельності самогубств також пов'язував 3 «хворобою суспільства» - його неблагоустроєм, роз'єднаністю, духовно-моральним занепадом. Такий стан суспільства соціолог назвав аномією і довів, що він $є$ потужним генератором самогубств [7, 261]. За обставин аномії індивід перебуває у стані невизначеності, не відчуває солідарності із соціумом, не має чітких орієнтирів, стандартів поведінки; суспільні деструкції у його психіці відображаються стражданнями, які трансформуються у розчарування, апатію, депресії, а відтак - у суїцидальність. Е.Дюркгайм підкреслював: «..якщо моральне середовище суспільства розклалося, то його суб'єкти не можуть не зазнавати на собі цього стану, оскільки у ньому перебувають» [5, 479].

Одного лише економічного благополуччя для лікування хвороб суспільства, зниження рівня суїцидальності, на думку Е.Дюркгайма, недостатньо. Гармонізації суспільства, зниженню чисельності самогубств сприятиме підвищення рівня інтегрованості суспільства, солідаризація особи та групи. Значущим антисуїцидальним потенціалом, який, за Дюркгаймом, за силою перевершує вплив усіх інших чинників, володіє релігія, особливо конфесії зі стійкою, непохитною доктриною $[5,162-186]$.

Суспільство істотно впливає на суїцидальність індивідів. Будучи 3 ним у нерозривному зв'язку, людина не може не зазнавати його впливу: усі позитивні чи негативні суспільні процеси відображаються у іiі психіці. Деструктивність, яку несе сучасне суспільство, стає безпосередньою причиною відхилень у поведінці індивіда, зокрема його аутодеструктивності. Ціннісна система сучасного технократичного суспільства призвела до порушення внутрішньої гармонії багатьох людей. Втрата природної автентичності, бездуховність, хибна система цінностей, дезінтеграція суспільства, відсутність визначених моральних орієнтирів поведінки - це наслідки у уилітарно-технократичної цивілізації. Усе це поглиблює внутрішні протиріччя людини, спричиняючи глибокі депресії і розчарування, що перебувають у прямому зв'язку 3 суїцидальністю. Це переконує, що нагальною життєвою необхідністю є глибоке оновлення суспільства.

Аналіз мотивів суїцидальної поведінки у середовищі сучасної студентської молоді дає підстави стверджувати, що даний віковий період $\epsilon$ чи не «найсприятливішим» для здійснення самогубства - час, коли особистість звертається до визначення сенсу життя, перегляду його цінностей.

На нашу думку, глибинні витоки кризових станів сучасної молоді - результат спотворених суспільних ідеалів та цінностей. Некрофільські тенденції світу суперечать утвердженню цінності людського життя. Надмірна міжособистісна конкуренція, психологічне та фізичне насилля в сім'ї, освітньому закладі, пропагування жорстокості на телеекранах, хибна ідентифікація 3 лідерами деструктивних культів і тоталітарних сект - корелює 3 поширенням агресії, формуванням суӥцидальності.

Як неможливо дати універсальне пояснення причин суӥциду, так і неможливо виокремити єдині чинники, що убезпечать людину від цієї думки. Серед антисуїцидальних чинників (установок i переживань, які перешкоджатимуть реалізації суїцидальних намірів) як соціально-психологічних орієнтирів, необхідних для вдоволеного життя людини у соціумі, позбавленого думок про самогубство, В.П.Москалець називає постійний пошук сенсу власного життя, орієнтацію на автентичні життєві цінності, ідеали, духовну активність, статусно-рольову відповідність, групове визнання, вияв комунікативних якостей, які забезпечують адекватне сприйняття реальності, знання власного комунікативного потенціалу та 


\section{Питання психології}

вміння його використовувати. Особливо значущою у протидії самогубству, на думку В.Москальця, $\epsilon$ роль духовності. Це обумовлюється тим, що у нестабільні історичні епохи міцність і стійкість людини визначається лише іiі духовним вкоріненням у вічність, вірою, надією та любов'ю $[9,143-$ 144].

В.В.Рибалка до чинників, які протидіють суїцидальним тенденціям і створюють особливий імунітет антисуїцидальної міцності особистості відносить: формування сенсу життя, життєвої перспективи, міцних зв'язків із близькими, родиною, суспільством, природою, соціальну адаптованість, інтегрованість 3 людьми та суспільством; наявність особистісних рис, які сприяють спілкуванню, - щирості, доброзичливості, взаєморозуміння, приязні; віру в Бога, у божественні цінності Всесвіту; підвищення значущості особистості у кризових ситуаціях, інтелектуальний опір смерті, в тому числі і самогубству; підвищення цінності людини як вершини еволюційно-генетичного процесу i носія генетичного та культурного багатства людства і Всесвіту; піднесення цінності особистості як конщентру історикокультурного процесу; піднесення цінності життя людини як невід'ємного елемента історико-культурного поступу людства [6, 12 $-13]$.

Ми погоджуємося 3 думкою науковців про те, що молоді вкрай необхідні цінності та ідеали, які б відкривали їм красу сенсу життя, були зорієнтованими на щось значно вище, ніж особистісні інтереси, обмежені власним егоїзмом, що суперечить думкам про самогубство.

Одним із найефективніших чинників протидії аутодеструктивності сучасної студентської молоді $\epsilon$ віра в Бога 3 iii потужним антисуїцидальним потенціалом.

У ході поглибленого теоретичного та емпіричного етапів дослідження нами було встановлено:

- серед віруючого студентства не було виявлено осіб з вираженою суїцидальністю; виражені суїцидальні тенденції були виявлені близько в третини невіруючих осіб;

- практично всі досліджувані, які назвали себе віруючими, виявили негативне ставлення до феномену самогубства й усього того, що так чи інакше знецінює життя, й, навпаки, - чимало студентів, які назвали себе невіруючими, намагалися виправдати суїциди інших чи виявляли індиферентне ставлення до них;

- віруюча студентська молодь помітно менше розчаровується у різних, важливих для молодої людини, сферах життя;

- у віруючих студентів суттєво вищий рівень самоприйняття, вони зорієнтовані на чітко окреслені смисли життя; але практично в усіх віруючих (за винятком невеликого відсотка) та невіруючих превалюють матеріальні смисли буття;

- у невіруючого студентства істотно вищий рівень самокритичності, самозвинувачення, аутоагресивних проявів, емоційної неврівноваженості;

- віруючі молоді люди оптимістичніше налаштовані на власне майбутнє;

- релігійна віра посідає вагоме місце у духовному житті сучасної української студентської молоді (враховуючи значну перевагу віруючих респондентів та їх ставлення до релігії), а це свідчить про те, що наше суспільство володіє потужним потенціалом протидії суїцидальності.

Звичайно, отримані результати не $\epsilon$ підставою для тверджень, що релігійна віра являє собою абсолютну панацею від серйозних розчарувань, депресивності, екзистенційних переживань, суїцидальності (ці психологічні стани - результат складної взаємодії багатьох чинників, серед яких i ендогенні, що спричиняють різноманітні розлади психіки особистості) $[9,19-24,162$ $-210]$.

Однак, іудаїзм та світові релігії християнство та мусульманство, які розвинулись на його основі, протягом усієї своєї історії були і є потужним суспільнокультурним антисуїцидальним чинником. Іудейська релігія завжди категорично засуджувала і засуджує самогубство своїх 


\section{Питання психології}

вірних, але наставляє, що єврейський воїн у випадку загрози полону, має вбити себе. Іудаїзм забороняє будь-які дії індивіда, спрямовані проти життя (контрацепцію, аборти, евтаназію, аутопсію).

Релігійна кара за вчинене самогубство серед мусульманських народів $\epsilon$ настільки нещадною, що не тільки дане явище, але й власне сама думка про суїцид вважається тут неприйнятною (за винятком суїцидів як альтруїстичної самопожертви на користь держави) [9, 32].

Християнство, яке зародилось у лоні іудаїзму, також доволі швидко наклало жорстку заборону на добровільне позбавлення себе життя після хвилі самогубств перших християн-мучеників, що прагнули таким чином якомога швидше постати перед Всевишнім.

Попри неможливість наукового доведення релігійних догм, чимала кількість науковців (В. Г. Джемс, В. П. Москалець, Г. У. Олпорт, В. Е. Франкл, К. Г. Юнг та ін.) прагнула дати науково-психологічне пояснення впливу релігії на смислове сповнення життя людини.

Так, на великий психотерапевтичний потенціал релігії вказував В.Г.Джемс: загальним для усіх релігій є звільнення від душевного страждання [4]. Позитивний потенціал релігійних почуттів долає меланхолію, депресію, відчай, безнадію, емоційний дисбаланс, які $\epsilon$ чинниками суїцидальності, надає людині душевної рівноваги, сповнює іiі життя сенсом. Релігія робить для людини легким і радісним те, що за інших обставин для неї $\epsilon$ «ігом суворої необхідності» $[4,55]$. Потужний емоційнокатарсичний ефект релігії $\epsilon$ вершиною іï психотерапевтичної ефективності. Катарсис звільняе від негативно забарвлених емоційних переживань та песимістичних думок, стимулюючи величезне душевне полегшення шляхом бурхливої розрядки гнітючого психічного напруження.

Г. У. Олпорт вважав, що релігія $є$ вкрай потрібним людині інтегратором ії психіки. За його спостереженнями, невротична особистість жалкує 3 приводу минулого, ненавидить своє сьогодення i боїться майбутнього. Релігія ж пропонує прощення за гідне жалю минуле, прийнятний, сповнений, якщо не радістю існування, то принаймні душевним спокоєм смисл теперішнього й оптимістичне сподівання на майбутнє, й цим самим потужно протидіє суӥцидальності [7, 112].

На важливість віри в Бога для психічного здоров'я особистості вказував і К. Г. Юнг. Він наголошував, що релігія $\epsilon$ універсальною системою психотерапії, яка зцілює нестерпні душевні страждання людини, стабілізує іiі психіку, і смерть Бога в iii душі неодмінно приведе до втрати людиною самої себе [14, 173].

Запоруку

успішного психотерапевтичного функціонування релігії К.Г.Юнг вбачав у співробітництві психологів i теологів: психотерапевт не зможе ефективно лікувати, якщо не візьме на озброєння релігійні системи зцілення: «людина, яка виступає від імені медицини, завжди є для іншої водночас і священником, рятівником її душі, а релігії - це системи, що зцілюють душевні недуги» $[7,70]$.

Західна психологія давно грунтовно й ефективно використовує релігію (iї життєдайні основи) у психотерапевтичній, психопрофілактичній діяльності. У США, західноєвропейських країнах сформувалась пасторська психологія - галузь знань, основною проблематикою якої $\epsilon$ шляхи ефективного психорегулятивного впливу священнослужителів на психіку людей. Грунтуючись на знаннях закономірностей психіки, пасторська психологія розробляє ефективні методи впливу на віруючих [7, 237].

Взірцем ефективної психопрофілактики засобами релігії є логотерапія В. Е. Франкла. Немас жодної іншої такої психотерапевтичної концепції особистості, яка була б настільки особистісно вистраждана, в горнилі пекла нацистського табору. Випробувавши на собі усі жахи нацистських концтаборів, В. Е. Франкл виходив 3 того, що релігійна віра надавала в'язням сенсу життя навіть у жахливих 


\section{Питання психології}

умовах Освенціма і Дахау. Він писав: «...чи не слід припустити, що над людським світом здіймається перевершуючий ii світ, чий надсмисл здатний надати смислу іiі стражданню» [12, 20]. Людина прагне віднайти сенс життя i переживає сприятливий для суїцидальності екзистенційний вакуум, якщо це прагнення залишається нереалізованим.

За переконанням В. Е. Франкла, людське життя за будь-яких обставин сповнене смислом, і навіть самогубець вірить у смисл, якщо не життя, то смерті [12, 177-182]. Логотерапія шукає абсолютно життєдайний смисл, який не втрачає свого потенціалу за будь-яких обставин. Саме таким $є$ життєвий смисл, який пропонує релігія.

Наведені аргументи переконують: особистість може щасливо та гідно існувати i вберегти себе від жаги самознищення, якщо матиме надособистісний (перевершуючий iii) смисл, який пропагує релігія, житиме не лише заради себе. Життя, позбавлене такого надособистісного смислу, спрямоване виключно на химерні цінності нестабільного матеріального світу, не захищене від відчаю, нудьги та песимізму - чинників, які перебувають у прямому зв'язку із суїцидальністю. Релігійна віра протидіє формуванню суїцидальних настроїв: володіє потужним зцілюючим потенціалом, рятує більшість від мук переживання екзистенційного абсурду, тривоги, особистісних розчарувань. Будучи могутньою життєдайною силою, віра в Бога інтегрує психіку людини на основі високих екзистенційних смислів, вселяє почування безпеки, спокій та оптимізм. Ідеали релігійної віри надають психіці людини стійкості та цілеспрямованості, забезпечують iii психологічний комфорт, впевненість та внутрішню нездоланність $[8,436]$.

У цьому руслі, аналіз результатів нашого емпіричного дослідження засвідчує наявність стурбованості у середовищі сучасного студентства (причому як віруючого, так i невіруючого) падінням рівня гуманізму, толерантності, доброзичливості серед населення, зростанням рівня суїцидальності.
Невимушені, ненав'язливі бесіди зі студентами 3 приводу використання гуманістичного потенціалу релігійної віри у профілактиці аутодеструктивності показали підтримку більшості: 63\% віруючих і 37\% невіруючих студентів, присутніх під час таких бесід, погодилися 3 думкою, що глибинним джерелом аутодеструктивності сучасної молоді $\epsilon$ наростання відчуженості, ворожості, агресії у міжособистісній взаємодії, надмірна егоїстична зосередженість більшості на меркантильних інтересах, й відтак - байдужості до проблем іншого, що суперечить релігійній етиці. Оскільки людина не може жити без любові, духовного спілкування з іншими - гординя, егоїзм та агресія «вбивають» iі, - як стверджує Р. М. Грановська [3, 284]. 19,38\% віруючих студентів безпосередньо пов'язують тенденцію зростання суїцидальності серед молоді 3 низьким рівнем духовності у сучасному суспільстві, серед них 2,23\% наголошують на домінуванні меркантильності навіть у сучасних релігійних установах, на кшталт: «Сьогодні у церквах більше говорять про гроші, аніж про Бога».

В унісон усьому вищезазначеному, варто підкреслити: «врятувати» стражденну душу сучасної людини від деструктивності (й відтак, i від аутодеструктивності) спроможний вітальний гуманістичний потенціал релігійної віри шляхом пробудження іï «гуманістичної совісті», що сприятиме моральному вдосконаленню особистості.

Відтак, проблема психопрофілактики суїцидальних тенденцій повинна розв'язуватись на рівні усього суспільства: шляхом прийняття та дотримання громадянами гуманістично-релігійних духовно-моральних цінностей, «пробудження» гуманістичної суспільної свідомості. Залучення до розв'язання проблеми широкої громадськості, духовенства, створення міцних гуманістичних засад навчання та виховання підростаючого покоління, розвиток та заохочення їх соціально-благодійної 


\section{Питання психології}

ініціативи, залучення до гуманістично спрямованих тренінгів, конференцій, семінарів, міжнародних духовно зоріснтованих проектів сприятиме профілактиці жорстокості, поширення деструктивності у молодіжному середовищі, прилученню молоді до високих гуманістично-релігійних духовно-моральних цінностей, виробленню у неї потужного антисуӥцидального імунітету.

Висновки. Результати нашого емпіричного дослідження засвідчили, що глибинним джерелом аутодеструктивності сучасної молоді є наростання відчуженості, агресії у міжособистісних взаємостосунках, надмірна егоїстична меркантильна зосередженість більшості, що суперечить релігійній етиці. Релігійна віра значуще протидіс формуванню суїцидальних тенденцій, володіючи потужним вітальним потенціалом, рятує від мук переживання екзистенційного абсурду, тривоги, особистісних розчарувань.

\section{Список використаних джерел}

1. Бердяев Н. О самоубийстве (психологический этюд) / Бердяев Н. - М.: МГУ, 1992. - С.3 -23

2. Бердяев Н.А.Философия свободы / Бердяев Н.А. - М.: Правда, 1989

3. Грановская Р.М. Психология веры / Грановская Р.М. - СПб.: Речь, 2004. - 576с. $418 \mathrm{c}$.

4. Джемс В. Многообразие религиозного опыта / Джемс В. - СПб.: Андреев и сыновья, 1993. -

5. Дюркгайм Е. Самогубство: Соціологічне дослідження / Дюркгайм Е.; [пер. з фр.]. - К.: Основи, 1998. - 519c.

6. Психологічна профілактика суїцидальних тенденцій в учнівської молоді: метод. рекомендації / [В.В. Рибалка]. - К.: ІПППО АПН України, КФ ВМУРоЛ «Україна», ПП Щербатих О.В., 2007. - 68c.

7. Предко О.І. Психологія релігії: історія, теорія, релігієзнавчі виміри: [монографія] / Предко О.І. - К.: Центр навчальної літератури, 2005. - 278c.

8. Психологія релігії: посіб. / [В.П.Москалець]. - К.: Академвидав, 2004. - 240с. - (Альмаматер).

9. Психологія суїциду: посіб. / [ред. В.П.Москальця]. - К.: Академвидав, 2004. - 288c. - (Альмаматер).

10. Пурич-Пейакович Йу. Самоубийство подростков / Йу. Пурич-Пейакович, Душан Й. Дуньич; [пер. с сербск.]. - М.: Медицина, 2000. - 168c.

11. Федоров В.А. Родители и дети их - самоубийцы / Федоров В.А. - Саратов, 1911.

12. Франкл В. Основы логотерапии. Психотерапия и религия / Франкл В. - СПб. Речь, 2000. $286 \mathrm{c}$.

13. Фромм Э. Анатомия человеческой деструктивности / Фромм Э. - М.: АСТ-ЛТД, 1998. - 672с. - (Классики зарубежной психологии). $480 \mathrm{c}$.

14. Юнг К.Г. Бог и бессознательное / Юнг К.Г.- М.: Олимп, ООО «Изд-во АСТ-ЛТД», 1998. -

\section{References}

1. Berdiaev N. O samoubyistve (psykholohycheskyi etiud) [About suicide (psychological study)] / Berdiaev N. - M.: MHU, 1992. - S.3 -23 (in Russian) Russian)

2. Berdiaev N.A.Fylosofyia svobody [Philosophy of freedom] / Berdiaev N.A. - M.: Pravda, 1989 (in

3. Hranovskaia R.M. Psykholohyia very [Psychology of faith] / Hranovskaia R.M. - SPb.: Rech, 2004.576s. (in Russian)

4. Dzhems V. Mnohoobrazye relyhyoznoho opyta [Diversity of religious experience] / Dzhems V. - SPb.: Andreev y sunovia, 1993. - 418s. (in Russian)

5. Diurkhaim E. Samohubstvo: Sotsiolohichne doslidzhennia [Suicide: Sociological research] / Diurkhaim E.; [per. z fr.]. - K.: Osnovy, 1998. - 519s. (in Ukranian)

6. Psykholohichna profilaktyka suitsydalnykh tendentsii $\mathrm{v}$ uchnivskoi molodi: metod. rekomendatsii [Psychological prevention of suicidal tendencies in student youth: a method. recommendations] / [V.V. 


\section{Питання психології}

Rybalka]. - K.: IPPPO APN Ukrainy, KF VMURoL «Ukraina», PP Shcherbatykh O.V., 2007. - 68s. (in Ukranian)

7. Predko O.I. Psykholohiia relihii: istoriia, teoriia, relihiieznavchi vymiry [Psychology of religion: history, theory, religious dimensions]: monohrafiia / Predko O.I. - K.: Tsentr navchalnoi literatury, 2005. - 278s. (in Ukranian)

8. Psykholohiia relihii [Psychology of religion]: posib. /V.P.Moskalets. - K.: Akademvydav, 2004. - 240s. -(Alma-mater). (in Ukranian)

9. Psykholohiia suitsydu [Psychology of suicide]: posib. /[red. V.P.Moskaltsia]. - K.: Akademvydav, 2004. - 288s. -(Alma-mater). (in Ukranian)

10. Purych-Peiakovych Yu. Samoubyistvo podrostkov [Adolescent suicide]/Yu. Purych-Peiakovych, Dushan Y. Dunych; [per. s serbsk.]. - M.: Medytsyna, 2000. - 168s. (in Russian)

11. Fedorov V.A.Rodytely y dety ykh - samoubyitsy [Parents and their children commit -suicide] / Fedorov V.A -Saratov, 1911. (in Russian)

12. Frankl V.Osnovy lohoterapyy. Psykhoterapyia y relyhyia [Basics of logotherapy. Psychotherapy and religion] / Frankl V.- SPb. Rech, 2000. - 286s. (in Russian)

13. Fromm Э. Anatomyia chelovecheskoi destruktyvnosty [Anatomy of human destructiveness] / Fromm Э. - M.: AST-LTD, 1998. - 672s. - (Klassyky zarubezhnoi psykholohyy). (in Russian)

14. Iunh K.H. Boh y bessoznatelnoe [God and the unconscious] / Yunh K.H.- M.: Olymp, OOO «Yzd-vo AST-LTD», 1998. - 480s. (in Russian)

\section{Резюме \\ Олейник А. В. кандидат психологических наук, \\ Национальный университет «Львовская политехника» \\ ПРЕВЕНЦИЯ СУИЦИДАЛЬНОСТИ СРЕДСТВАМИ РЕЛИГИОЗНОЙ ВЕРЫ В СРЕДЕ СТУДЕНЧЕСКОЙ МОЛОДЕЖИ}

В статье в результате углубленного анализа проблемы влияния веры в Бога на суицидальность субъекта теоретически обосновано и экспериментально доказано значимое антисуицидальное влияние религиозной веры на сознание и поведение современного украинского студенчества; эмпирически установлено гармонизирующее влияние веры в Бога на психику студенческой молодежи; обоснованно особенности превенции суиџидальности и психокоррекции суицидально опасных состояний средствами религиозной веры и, следовательно, формирование отношения к жизни как к наивысшей человеческой ценности и отношения к суициду как к посягательству на наиболее ценное.

Ключеввые слова: аутодеструктивность; религиозная вера; суичид; студенческая молодежь; превенщуия.

\section{Summary \\ Oliynyk A. V. Candidate of Psychological Sciences, National University «Lviv Polytechnic»}

\section{PREVENTION OF SUICIDALITY BY MEANS OF RELIGION AMONG STUDENTS}

Introduction. In article on the basis of the detailed analysis approaches to the problem in influence of religious faith on a suicide of subject (persons and group) in theory is reasonably and experimentally wellproven anti-suicidal influence offaith in God on consciousness and behavior of the modern Ukrainian student.

Purpose of article is to substantiate the effectiveness of the life-affirming potential of religious faith in combating suicide among students, expanding the system of preventive measures for the emergence of selfdestructiveness.

Originality of obtained results is that the psychological features of the anti-suicidal influence of religious faith on the consciousness and behavior of students are substantiated, which are: in a viable religious solution to the basic human problem of finiteness of earthly existence, interpretation of life as the highest value and suicide as encroachment on the most valuable; the viability of the religious justification of the meaning of human suffering, the fallacy of the narrowly selfish utilitarian-mercantile way of life; focus on highly spiritual existential meanings.

Methods. In the course of solving the set tasks the methods of L. Sobchyk SMDO (standardized method of personality research) were used; method of differential diagnosis of depressive states Zunge (adaptation of T.I. 


\section{Питання психології}

Balashova), questionnaire of B. Luban-Plots (to determine the risk of suicide), questionnaire of N. Pezeshkian (to diagnose people with suicidal tendencies), author's questionnaire to identify the relationship of religious faith with suicidal tendencies among student youth.

Conclusion. As a result of in-depth theoretical and empirical analysis of the problem is proved common harmonizing influence of faith is empiric educed in God on the psyche of student young people; the psychological features of anti-suicidal influence of religious faith are reasonable on consciousness and behavior of students that consists: in life-asserting religious decision of basic human problem of extremity of earthly existence, interpretation of life as the greatest value and suicide as encroachment on more valuable in all; life-givingness of religios ground of sense of the human suffering; fallaciousness of selfish, utilitarianmercantile way of life, orientation on spiritual senses of existence. The problem of psychoprevention of suicidal tendencies should be solved at the level of the whole society. It can be done by means of adopting and adhering to humanistic and religious moral values by citizens, «awakening» humanistic social consciousness. Involving community, clergy, creating strong humanistic foundation of young peoples, educating and upbringing, developing and encouraging their social-charitable initiative, involving in training conferences, seminars, international spiritually oriented projects are sure to facilitate preventing cruelty, spreading destructiveness among young people and attracting them to high moral values, to producing a powerful antisuicidal immunity.

It remains relevant to study the deep psychological anti-suicidal mechanisms of faith in God, confession, prayer and other spiritual practices in combating suicide, the establishment of specialized centers in schools, including training, which in case of predicted risk of suicide students will take into account the presence of of her religious faith, to use its life-giving, anti-suicidal potential during the organization of psychoprophylactic and psychocorrectional work.

Key words: self-destructiveness; religion; suicide; students; prevention.

Recelved/Поступила: 23.10.21. 